Tersedia Online di http://journal.unismuh.ac.id/index.php/otoritas

Otoritas : Jurnal Ilmu Pemerintahan, 6 (1), April 2016, 42-49

\title{
Konflik Elit Dalam Pemilihan Walikota dan Wakil Walikota di Gorontalo Tahun 2013
}

\author{
Irfin Nehrun*) \\ Program Studi Ilmu Pemerintahan, Fakultas Ilmu Sosial dan Ilmu Politik, Universitas Gorontalo, \\ Jalan Abd. Wahab No. 247, Gorontalo, Indonesia
}

Diterima : 5 Februari 2016; Disetujui : 28 Maret 2016; Dipublikasikan 14 April 2016

\begin{abstract}
The aims of the study were to analyze the causes of elite conflict and the process of elite conflict in the election of Mayor and Deputy Mayor of Gorontalo 2013. The research method was a qualitative method with in-depth interview techniques and documentation. Data and interviews results were processed with qualitative analysis. The Results of research and discussion indicated that there was a conflict of elites in the elections of Mayor and Deputy Mayor of Gorontalo in 2013, which were caused by political elite feud accured prior to and during the election. The conflict before elections happened between Rusli Habibie, the Chairman of DPD Golkar Gorontalo nd Adhan Dambea. Adhan Dambea was fired from his membership of Golkar Party because he was considered of structurally rebellious against the party's and decision. Elite conflict during the elections happened between party elite and elite candidate and elite organizers. The conflict caused all the elections phases did not run normally, which made Gorontalo City did not have a definitive Mayor and Deputy Mayor for 14 months.
\end{abstract}

Keywords: conflict; elite; major election

\begin{abstract}
Abstrak
Penelitian ini bertujuan untuk menganalisis penyebab terjadinya konflik elit dan proses terjadinya konflik elit dalam pemilihan Walikota dan Wakil Walikota Gorontalo Tahun 2013. Metode penelitian menggunakan wawancara mendalam dan dokumentasi. Data diolah dan dianalisis dengan analisis kualitatif.Hasil penelitian menunjukan bahwatelah terjadi konflik elit dalam pemilihan Walikota dan Wakil Walikota Gorontalo tahun 2013 yang disebabkan oleh adanya perseteruan elit politik yang terjadi sebelum Pilkada dan saat Pilkada. Konflik sebelum Pilkada terjadi antara Ketua DPD Partai Golkar Provinsi Gorontalo Rusli Habibie dengan Adhan Dambea selaku Ketua Dewan Pertimbangan Partai Golkar Kota Gorontalo. Adhan Dambea dipecat dari keanggotaan Partai Golkar karena dianggap melakukan pembangkangan secara struktural atas keputusan partai. Sementarakonflik elit saat Pilkada berlangsungterjadi antara elit partai dengan elit calon, calon dengan calon, serta elit calon dengan penyelenggara. Konflik tersebut mengakibatkan seluruh tahapan Pilkada tidak berjalan secara normal sehingga Kota Gorontalo selama empat belas bulan tidak memiliki walikota dan wakil walikota defenitif.
\end{abstract}

Kata kunci : konflik; elit; pemilihan walikota

Cara Penulisan Sitasi : Nehrun, I. (2016). Konflik Elit Dalam Pemilihan Walikota dan Wakil Walikota di Gorontalo Tahun 2013. Otoritas : Jurnal Ilmu Pemerintahan, 6 (1), 4249.

*)Penulis Korespondensi.

E-Mail : irfinnehrun@gmail.com

Copyright (C) 2016, Otoritas : Jurnal Ilmu Pemerintahan, p-ISSN: 2088-3706, e-ISSN: 2502-9320 
Tersedia Online di http://journal.unismuh.ac.id/index.php/otoritas

Otoritas : Jurnal Ilmu Pemerintahan, 6 (1), April 2016, 43

\section{Pendahuluan}

Dinamika politik lokal dalam perebutan kekuasaan pada rezim Orde Lama dan Orde Baru dipandang kurang begitu menarik, karena jarang terjadi konflik antar elit politik baik di level pemilihan Gubernur, Bupati maupun Walikota. Pasca reformasi berlangsung dinamika politik nasional berubah total dinamika politik daerah berubah. Semua orang dan kelompok masyarakat merasa lega karena terlepas dari sebuah beban berat yang bernama otoritarianisme dibawah rezim pemerintahan Soeharto (Gaffar, 2006). Pasca Orde Baru berkuasa, pola pergantian kepemimpinan di daerah menimbulkan konflik kepentingan yang sulit dihindari. Berbagai masalah yang terjadi mendorong timbulnya konflik dan integrasi karena adanya persamaan dan perbedaan kepentingan sosial (Setiadi \& Usman, 2011).

Salah satu bentuk konflik sosial ialah konflik politik. Karena konflik politik adalah bagian dari konflik sosial, konflik politik mempunyai ciri-ciri yang mirip dengan konflik sosial. Hal yang membuat konflik sosial berbeda dari konflik politik adalah kata "politik" yang membawa konotasi tertentu bagi istilah konflik politik. Tidak seperti konflik sosial, konflik politik mempunyai konotasi politik yakni mempunyai keterkaitan dengan negara/ pemerintah, para pejabat politik/ pemerintahan, dan kebijakan. Konflik politik merupakan konflik kelompok, sehingga yang dimaksud dengan konflik kelompok adalah konflik yang terjadi antara dua kelompok atau lebih (Rauf, 2001).

Agustino (2009) memandang elit politik sebagai aktor politik yang aktif berpolitik. Dalam pandangan Varma (2010), menegaskan bahwa setidaknya masyarakat terbagi dalam dua kategori yang mencakup: pertama, sekelompok kecil manusia yang berkemampuan dan karenanya menduduki posisi untuk me- merintah dan kedua, sejumlah besar massa yang ditakdirkan untuk diperintah.

Konflik terjadi karena tidak ada konsensus antara pribadi-pribadi atau kelompok-kelompok didalam masyarakat. Konsensus akan tercipta bila ada kesepakatan antara mereka yang berkonflik sehingga tidak membuka peluang adanya perbedaan pendapat dalam masalah yang disepakati tersebut. Selain itu, keberhasilan dalam mengelola konflik ditentukan oleh ketepatan dalam memilih teknik pengelolaan, kemampuan pihak ketiga atau pemimpin dalam mengelola konflik, dan kesediaan pihak-pihak yang terlibat konflik untuk menyelesaikan konflik dengan mengunakan metode dominasi, kompromis, dan pemecahan masalah secara integratif merupakan metode yang paling banyak digunakan dalam penyelesaian konflik (Wahyudi, 2011).

Lahirnya Undang-Undang Nomor 32 tahun 2004 tentang Pemerintahan Daerah, yang diikuti dengan pelaksanaan Pemilihan Kepala Daerah secara langsung, telah memberikan spirit baru bagi masyarakat karena bisa berpartisipasi secara langsung. Akan tetapi dalam prakteknya Pilkada langsung memang masih banyak mengalami hambatan hingga menimbulkan konflik. Dalam posisi tersebut memang Pemerintah Pusat terus melakukan berbagai upaya untuk mengatasi konflik yang terjadi, namun selalu gagal menemukan titik temu yang seimbang sehingga muncul protes dan persoalanpersoalan politik lokal (Nas, 2007).

Dalam konteks pergantian kekuasaan dari rezim lama kepada rezim baru, ternyata di beberapa daerah menimbulkan persoalan. Tajamnya kepentingan politik antar kekuatan politik maupun intrakekuatan politik, mengakibatkan sejumlah konflik dalam perebutan jabatan -jabatan politik seperti Gubernur, Bupati dan Walikota seringkali tidak dapat dihindari. Hasil penelitian LIPI (2005), menunjukan bahwa pola pergantian kekuasaan di tingkat lokal yang sering 
menyebabkan konflik, sebenarnya bukanlah persoalan baru. Selama kurun waktu transisi (1998-2002) terjadi kurang lebih 6 kasus pemilihan Gubernur yang bermasalah dan 10 kasus pemilihan bupati dan walikota diseluruh Indonesia yang menyebabkan konflik politik.

Hasil penelitian The Habibie Centre (2013), saat di mana Pilkada langsung digelar (2005-2013) telah terjadi konflik dalam Pilkada yang skalanya cukup beragam yang terjadi di 10 provinsi di Indonesia. Data penelitian menunjukan sedikitnya terdapat 585 kasus kekerasan dalam Pemilukada yang mengakibatkan korban tewas 47 orang, cedera 510 orang, bangunan rusak 416 buah.Konflik ini dipicu oleh isu yang berbeda-beda antara satu kasus dengan kasus lainnya, tetapi secara umum, isu yang muncul adalah terjadi perbedaan penafsiran dari segi hukum atas hasil pemilihan, adanya kelompok pendukung yang tidak menerima hasil pemilihan sehingga menimbulkan protes dan tindakan anarkis, hasil pemilihan dianggap cacat hukum, adanya isu politik uang dan penolakan hasil pemilihan karena calon diduga korupsi.

Konflik elit dalam Pilkada merupakan hal yang biasa terjadi karena ukuran konfliknya relatif kecil, namun jika konflik Pilkada terjadi secara terus menerus di daerah maka tentu akan menjadi masalah besar. Konflik yang terjadi saat Pilkada di Kota Gorontalo tahun 2013 telah menyebabkan ketidakstabilan politik daerah. Konflik elit politik ini telah ada sebelum Pilkada dilaksanakan yang kemudian ikut memengaruhi proses tahapan Pilkada. Konflik ini berlangsung selama 17 bulan, yakni sejak dimulainya tahapan pencalonan pada tanggal 3 Desember 2012 sampai dengan keluarnya putusan Mahkamah Konstitusi tanggal 24 April 2014. Selain itu, konflik Pilkada ini juga telah mengakibatkan Kota Gorontalo selama kurun waktu 14 bulan, di mana sejak bulan Maret 2013 sampai dengan bulan Mei 2014 tidak memiliki Walikota dan Wakil
Walikota definitif untuk menjalankan roda pemerintahan. Adapun penelitian ini bertujuan untuk menganalisis penyebab terjadinya konflik elit dan proses terjadinya konflik elit dalam pemilihan Walikota dan Wakil Walikota Gorontalo Tahun 2013.

Konflik terjadi karena tidak ada konsensus antara pribadi-pribadi atau kelompok-kelompok didalam masyarakat. Sebaliknya, konsensus terbentuk karena tidak ada konflik antara orang-orang atau kelompok-kelompok yang berkonsensus tersebut. Dengan kata lain, konsensus tercipta bila ada kesepakatan antara mereka itu sehingga tidak membuka peluang adanya perbedaan pendapat dalam masalah yang disepakati tersebut.

Terjadinya konflik disebabkan adanya kegiatan-kegiatan yang dilakukan anggota masyarakat dalam memperebutkan sumber-sumber, posisi atau kedudukan atau jabatan yang dianggap langka dalam masyarakat. Penyebab lain adalah kecenderungan manusia untuk menguasai orang lain. Hal in berarti kecenderungan manusia untuk berkuasa menjadi salah satu penyebab konflik.

Penyelesaian konflik didasarkan atas adanya perubahan pandangan dari satu atau semua yang terlibat konflik sehingga tidak ada lagi pertentangan antara mereka. Dengan demikian terjadi perubahan dalam pandangan dari salah satu atau semua pihak yang terlibat. Hal inilah yang membuat penyelesaian konflik bukanlah pekerjaan yang mudah karena amat sulit bagi seseorang untuk mengubah pendapatnya yang berbeda dan bertentangan dengan orang lain tersebut. Meskipun sulit, penyelesain konflik mutlak diperlukan untuk mencegah: (1) semakin mendalamnya konflik, yang berarti semakin tajamnya perbedaan antara pihak-pihak yang berkonflik ; (2) semakin meluasnya konflik, yang berarti semakin mendalam dan meluas. Bila tidak ditemukan cara penyelesaikan konflik yang efektif, konflik dapat menimbulkan 
ancaman disintegrasi masyarakat, yaitu terpecahnya masyarakat sesuai dengan garis yang memisahkan pihak-pihak yang terlibat konflik sehingga seluruh atau sebagian besar warga masyarakat terlibat dalam pertentangan yang dapat menghasilkan dua kelompok masyarakat yang terpisah dan bermusuhan. Bila ini terjadi hubungan sosial yang harmonis antara warga-warga masyarakat tidak dapat berjalan, yang berarti terjadinya gangguan terhadap ketenangan dan ketertiban masyarakat (Rauf, 2001).

Perebutan posisi dalam kekuasaan politik yang terjadi antara Rusli Habibie dan Adhan Dambea secara nyata merupakan perebutan terhadap sumber daya yang tergolong langka dan terbatas. Kedua kelompok ini melihat posisi politik yang langka tersebut mempunyai daya tarik yang tinggi sehingga menjadi rebutan bagi keduanya. Hal ini karena berbagai sebab, pertama adalah tingginya penghargaan yang melekat pada jabatanjabatan politik. Jabatan politik memberikan kepada para penguasa politik kekuasaan yang besar terhadap masyarakat karena bisa membuat keputusankeputusan penting yang menyangkut kepentingan rakyat banyak. Di samping itu, yang bisa menduduki jabatan tersebut bukanlah sembarang, tetapi orang-orang yang dianggap mempunyai kelebihankelebihan dibandingkan kebanyakan orang. Oleh karena itu keinginan menjadi terkenal dan dihormati oleh rakyat merupakan salah satu alasan utama bagi adanya daya tarik posisi politik.

Kecenderungan Adhan Dambea sebagai penguasa politik berusaha untuk mempertahankan posisi politik yang dimilikinya, maka tak mengherankan ia membela diri. Kelompoknya menyerang dan menyalahkan pihak yang menggugatnya sebagai penguasa politik melalui lembaga pengadilan. Upaya mencekal Adhan Dambea ini dilakukan oleh kelompok Rusli Habibie sebagai elit kelas penguasa yang memiliki kemampu- an yang efektif memonopoli pos-pos kunci dalam politik dan pemerintahan.

Hambatan terbesar bagi konsensus dalam penyelesaian sengketa Pilkada Kota Gorontalo adalah sikap masing-masing kelompok elit calon yang tidak mau menerima begitu saja hasil Pilkada yang telah diputuskan oleh KPU Kota Gorontalo. Kelompok elit calon ini tetap berpegang teguh pada pendapat yang dianutnya secara fanatik tanpa membuka kemungkinan bagi terjadinya perubahan terhadap pendapat tersebut. Sehingga untuk merubah pandangan mereka tersebut hanya dapat dicapai melalui lembaga pengadilan yang menanggani sengketa Pilkada. Sikap dan pandangan seperti ini sangat sulit untuk mewujudkan konsensus di antara kelompok yang berkonflik karena masing-masing menganggap pendapatnya yang benar.

Ada beberapa penelitian terdahulu menyangkut konflik dalam suksesi kepemimpinan. Abbas (2011) yang meneliti tentang konflik elit lokal dalam pemilihan kepala daerah di Maluku Utara. Dalam penelitian tersebut didapatkan hasil bahwa pertarungan antara elit lokal terjadi dalam beberapa arena, baik di arena yang berskala kecil maupun di arena besar. Konflik yang terjadi berakar dari pembentukan propinsi Maluku Utara pada tahun 1999, persaingan elit lokal, dan pemilihan kepala daerah Maluku Utara 2001-2002. Konfigurasi elit lokal yang ada di Maluku Utara sendiri terbagi dalam tiga bagian besar, yaitu elit tradisional, elit baru, dan elit lokal. Pemilihan kepala daerah Maluku Utara 2001-2002 bisa dibilang merupakan arena pertarungan elit lokal Maluku Utara yang terjadi dalam skala besar, dalam arena ini Abdul Gaffur yang sebelumnya memenangkan pemilihan, akhirnya harus kalah dari Thaib Armayin.

Penelitian lain diteliti oleh Al-Fairi (2011) yang meneliti tentang Pemilihan Umum Kepala Daerah (Pemilukada) Secara Langsung "Sebuah Pilihan Model 
Tersedia Online di http://journal.unismuh.ac.id/index.php/otoritas

Otoritas : Jurnal Ilmu Pemerintahan, 6 (1), April 2016, 46

Pemerintahan Daerah Demokratis", dalam penelitian ini ditemukan hasil bahwa keberadaan pemilihan umum tingkat daerah secara langsung merupakan pilihan yang benar dan menjadi penciri utama dalam model pemerintahan daerah yang demokratis.

Sedangkan Armunanto (2015) meneliti tentang Potensi Konflik pada Pemilihan Kepala Daerah Langsung di Kota Makassar Tahun 2013, dalam penelitian ini menghasilkan kesimpulan bahwasanya factor sosiologis dan institusional menjadi faktor penting dalam potensi konflik pada pemilihan kepala daerah langsung di kota Makassar. Penelitian ini merekomendasikan partai politik, KPU, dan aparat keamanan menjadi responsif sebelum konflik meningkat.

Dari beberapa penelitian terdahulu itulah maka penulis mengarahkan penelitian ini pada upaya menganalisa penyebab terjadinya konflik elit dan proses terjadinya konflik elit dalam pemilihan Walikota dan Wakil Walikota Gorontalo Tahun 2013.

\section{Metode Penelitian}

Metode penelitian menggunakan metode kualitatif. Lokasi penelitian di Kota Gorontalo dengan memusatkan pada beberapa tempat seperti di Kantor KPU Kota Gorontalo, Sekretariat Panwaslu Kota Gorontalo, Kantor DPD Partai Golkar Provinsi Gorontalo, DPD Partai Golkar Kota Gorontalo, dan Sekretariat AD Center. Lokasi ini dipilih karena merupakan tempat berlangsungnya konflik antar elit selama proses Pemilihan Walikota dan Wakil Walikota Gorontalo tahun 2013. Sedangakn pengumpulan data melalui wawancara dengan Ketua DPD Partai Golkar Propinsi Gorontalo, Ketua Dewan Pembina dan Ketua DPD Partai Golkar Kota Gorontalo, Ketua dan anggota KPU Kota Gorontalo, Ketua dan anggota PANWASLU Kota Gorontalo, dan tokoh masyarakat. Analisis data secara deskriftif kualitatif, mengambarkan secara riil variabel yang mengakibatkan terjadinya konflik elit pada penyelengaraan pemilihan Walikota dan Wakil Walikota Gorontalo tahun 2013, serta berupaya mencari solusi yang diinginkan elit yang berkonflik.

\section{Hasil dan Pembahasan}

Penelitian ini menunjukkan secara deskriptif bahwa konflik elit yang terjadi dalam Pemilukada, merupakan suatu fenomena politik lokal yang tidak bisa dihindari dalam setiap proses penyelenggaraan Pilkada. Konflik elit membawa implikasi positif dan negatif terhadap proses demokratisasi yang sedang praktekan di Indonesia dewasa ini.Memperhatikan berbagai data dan informasi yang penulis dapatkan selama proses penelitian, ditemukan akar penyebab terjadinya konflik elit dalam Pilkada Kota Gorontalo tahun 2013.Hasil penelitian menunjukan bahwa adanya konflik elit dalam Pemilihan Walikota dan Wakil Walikota Gorontalo tahun 2013 disebabkan oleh adanya perseturuan elit Partai Golongan Karya antara Rusli Habibie sebagai Ketua DPD Partai Golkar Provinsi Gorontalo dan Adhan Dambea sebagai Ketua Dewan Pertimbangan DPD Partai Golkar Kota Gorontalo. Keduanya adalah merupakan Gubernur Gorontalo dan Walikota Gorontalo.

Konflik ini sudah lama terjadi yakni sejak tahun 2009 di mana saat Musyawarah Nasional Partai Golkar di Pekan Baru Riau, telah terjadi gesekan akibat perbedaan pilihan politik saat Munas berlangsung. Rusli Habibie berhasil menghimpun dukungan dari 5 DPD tingkat II se Provinsi Gorontalo untuk memilih Aburizal Bakrie, sedangkan Adhan Dambea dengan dukungan 1 DPD tingkat II mendukung Surya Paloh. Pasca diselenggarakannya Munas Riau 2009, ditingkat daerah diikuti oleh pelaksanaan Musda tingkat I dan II. Akibat perbedaan dukungan politik saat Munas Riau ikut memengaruhi pelaksanaan Musda di daerah. 
Tersedia Online di http://journal.unismuh.ac.id/index.php/otoritas

Otoritas : Jurnal Ilmu Pemerintahan, 6 (1), April 2016, 47

Selain itu, Konflik ini dipicu oleh perebutan kekuasaan dalam menduduki kursi Ketua DPD Partai Golkar Provinsi Gorontalo tahun 2009 pasca ditinggalkan Fadel Muhammad kerena telah mendapat Posisi Wakil Ketua Umum DPP Partai Golkar.Fadel Muhammad lebih memilih Rusli Habibie menjadi ketua DPD Partai Golkar Provinsi Gorontalo ketimbang memilih Adhan Dambea. Pada hal Adhan Dambea sebelumnya merupakan calon kuat ketua DPD I karena telah mendapatkan dukungan dari semua DPD Kabupaten/Kota se Provinsi Gorontalo.

Menjelang Pilkada Gubernur Gorontalo tahun 2011, Walikota Gorontalo Adhan Dambea lebih memilih mendukung calon Gubernur Gusnar Ismail dari Partai Demokrat ketimbang mendukung Rusli Habibie yang dicalonkan Partai Golkar sebagai Calon Gubernur Gorontalo periode 2012 - 2017. Sikap politik Adhan Dambea ini menyebabkan DPP Partai Golkar pada tanggal 16 Agustus 2011 melakukan pemecatan terhadap Adhan Dambea sebagai kader dan anggota Partai Golkar.

Selain penyebab konflik elit yang terjadi di internal Partai Golkar, hal tersebut ikut menyebabkan kekisruhan saat Proses dan tahapan Pilkada Walikota Gorontalo berlangsung tahun 2013. Pilkada Walikota dan Wakil Walikota Gorontalo tahun 2013 diikuti oleh empat pasangan calon, tiga pasangan calon diusung oleh Partai Politik yakni Feriyanto Mayulu - Abdurrahman Bachmid (FB) PAN dan PKS, Marten Taha - Budi Doku (MADU) Partai Golkar dan A.W Talib Ridwan Monoarfa (WAHID) PPP dan PDK, serta satu pasangan calon lainnya melalui jalur perorangan yakni Adhan Dambea Inrawanto Hasan (DA'I).

Selama proses Pilkada berlangsung terjadi pemecatan terhadap 3 orang Komisioner KPU Kota Gorontalo masingmasing Ketua KPU Rizan Adam, dan Hadi Sutrisno, Djarnawi Datau sebagai anggota. Ketiganya di berhentikan oleh DKPP kare- na terbukti melanggar Kode Etik dikarenakan telah meloloskan Adhan Dambea Inrawanto Hasan (DA'I) sebagai calon yang tidak memenuhi syarat. Pasangan DA'I dicoret karena masalah Ijazah SD, di mana Adhan Dambea hanya menggunakan Surat Keterangan Tamat (SKT) saat pendaftaran, sedangkan yang dipersyaratkan dalam PKPU Nomor 9 Tahun 2012, adalah Surat Keterangan Penganti Ijazah (SKPI).

Proses tersebut membuat KPU Kota Gorontalo memutuskan mencoret pasangan DA'I pada tanggal 27 Maret 2013, satu hari menjelang pemungutan suara yang dilaksanakan tanggal 28 Maret 2013. Adhan Dambea melakukan gugatan melalui PTUN Manado, Banding di PT.TUN Makassar hingga Kasasi di Mahkamah Agung R.I, tapi semuanya di tolak. Mahkamah Konstitusi memutuskan sengketa Pilkada Kota Gorontalo sejak disidangkan pada 30 April 2013 hanya menghasilkan Putusan Sela, kemudian dilanjutkan pada tanggal 24 April 2014 diputuskan, dan memenangkan pasangan Marten Taha - Budi Doku (MADU) sebagai Walikota dan Wakil Walikota Gorontalo periode 20132018.

Penelitian ini menunjukan bahwa konflik dalam pemilihan Walikota dan Wakil Walikota Gorontalo ini baru bisa diselesaikan di Mahkamah Kosntitusi. Selama proses tersebut berlangsung, terjadi perselisihan atau persengketaan, baik secara individu maupun kelompok. Semua pihak memiliki keinginan untuk saling menjatuhkan, menyingkirkan atau mengalahkan. Proses dari konflik Pilkada tersebut turut memberikan dampak atas jalannya pembangunan di Kota Gorontalo baik sebelum Pilkada maupun sesudah Pilkada.Salah satu penyebab terjadinya konflik elit antara Gubernur Gorontalo Rusli Habibie dan Walikota Gorontalo Adhan Dambea adalah akibat perebutan kekuasaan dalam kepengurusan DPD I Partai Golkar Provinsi Gorontalo saat Musda tahun 2009. Kekalahan Adhan 
Dambea dalam Musda tersebut membuat sikap politik yang bersangkutan saat Pilkada Gubernur Gorontalo tahun 2011 tidak sejalan dengan kebijakan Partai Golkar.

Adhan Dambea yang saat itu menjabat sebagai Ketua Dewan Pertimbangan Partai Golkar Kota Gorontalo dipecat oleh DPP Partai Golkar tahun 2011 atas usulan Rusli Habibie sebagai Ketua DPD I Partai Golkar Provinsi Gorontalo. Konflik antara dua politisi senior Gorontalo tersebut sudah lama berlangsung. Konflik tersebut baru memasuki puncaknya pada saat pelaksanaan pemilihan Walikota dan Wakil Walikota Gorontalo tahun 2013. Berbagai kejadian menarik terjadi selama proses Pilkada Kota Gorontalo berlangsung, mulai dari aksi saling protes, saling gugat, bahkan saling lapor antara lembaga pengawas dan lembaga penyelenggara tidak bisa dihindari.

Implikasi dari konflik internal tersebut, mengakibatkan proses dan tahapan Pilkada Walikota Gorontalo tahun 2013 tidak berjalan normal. Sejak proses pencalonan bakal calon desember 2012 sampai dengan putusan Mahkamah Konstitusi pada April 2014 menghabiskan waktu selama 17 bulan. Adanya gugatan antar pasangan calon kelembaga PTUN Manado saat di mana tahapan sedang berjalan, demikian juga adanya laporan Panswaslu terhadap keputusan penetapan pasangan Calon Walikota oleh KPU, telah mengakibatkan adanya pemecatan terhadap 3 orang komisioner KPU Kota Gorontalo oleh Dewan Kehormatan Penyelenggara Pemilu (DKPP), serta sejumlah permasalahan lainnya yang terjadi baik sebelum Pilkada maupun sesudah Pilkada dilaksanakan.

Selain itu,adanya keputusan pencoretan yang dilakukan oleh Komisi Pemilihan Umum Kota Gorontalo terhadap salah satu pasangan calon Walikota dan Wakil Walikota Adhan Dambea dan Inrawanto Hasan (DA'I) sehari menjelang pemungutan suara pada tanggal 27 Maret 2013 menyebabkan situasi politik kacau balau. Keputusan KPU tersebut dinilai tidak konsisten oleh pasangan Adhan Dambea - Inrwanto Hasan, KPU bekerja dibawah tekanan Gubernur dan diduga telah menerima sejumlah uang dari Rusli Habibie yang memiliki kepentingan besar untuk memenangkan Marten Taha - Budi Doku dari Parti Golkar. Proses pencoretan ini membuat situasi Pilkada Walikota Gorontalo tahun 2013 semakin memanas di mana pencoretan tersebut merupakan satu hal yang langka bahkan tidak pernah ada dalam sejarah pemilihan kepala daerah di Indonesia sejak 2005-2013.

\section{Kesimpulan}

Hasil penelitian tersebut dapat disimpulkan bahwa penyebab terjadinya konflik elit dalam pemilihan Walikota dan Wakil Walikota Gorontalo tahun 2013 disebabkan oleh adanya konflik yang terjadi di internal Partai Golkar Provinsi Gorontalo antara Gubernur Rusli Habibie dengan Walikota Gorontalo Adhan Dambea. Selain itu proses terjadinya konflik elit dalam Pilkada Walikota 2013 dimulai sejak tahapan verifikasi berkas ijazah pasangan calon sampai dengan putusan hasil sengketa Pilkada Walikota tahun 2014.

Selama proses tahapan berlangsung terjadi banyak insiden dalam pengambilan keputusan, mulai dari pemecatan 3 komisioner KPU Kota Gorontalo, Putusan PTUN Manado yang menganulir keputusan KPU Kota Gorontalo dalam meloloskan pasangan calon, serta pencoretan pasangan Adhan Dambea - Inrawanto Hasan sehari menjelang hari pencoblosan pada tanggal 27 Maret 2013.

Adapun saran penulis yaitu menyarankan agar semua elit politik lokal dapat lebih mengedepankan pendidikan politik yang baik kepada masyarakat maupun kepada pengikut dan pendukungnya. Mengunakan cara-cara yang 
Tersedia Online di http://journal.unismuh.ac.id/index.php/otoritas

Otoritas : Jurnal Ilmu Pemerintahan, 6 (1), April 2016, 49

bijak dan elegan dalam menyelesaikan setiap masalah diinternal Partai Politik agar bisa terwujud keteraturan politik dimasa yang akan datang. Selain itu perlu adanya mekanisme penyelesaian Konflik Pilkada oleh rezim Pemilu, yakni KPU, Panwaslu, DKPP, dan Mahkamah Konstitusi dari sisi waktu sudah diatur penyelesaiannya, yakin Panwaslu 3 hari, DKPP dan MK masing-masing 14 hari, namun lembaga lainnya yang terkait seperti PTUN, PT.TUN ditingkat Banding, dan Mahkamah Agung R.I ditingkat Kasasi tidak, ada waktu yang mengatur penyelesaian sengketa Pilkada. Sehingga sangat perlu disarankan agar ada kesepakatan bersama antara KPU, Bawaslu, DKPP, MK melibatkan MA dalam menyelesaikan sengketa Pilkada sesuai kewenangannya masing-masing tanpa menggangu waktu dan tahapan penyelenggaraan Pilkada diwaktu-waktu yang akan datang. Penulis menyarankan agar mekanisme perekrutan terhadap komisioner KPU dan Panwaslu di daerah perlu dievaluasi kembali. Dari temuan penulis dalam penelitian, terdapat beberapa kali pemecatan terhadap komisioner KPU Kota Gorontalo akibat pelanggaran Kode Etik. Ada kedekatan hubungan emosional yang kuat antara beberapa komisioner KPU dan Panwaslu dengan kebanyakan elit politik lokal, sehingga potensi konflik kepentingan sangat dimunkinkan terjadi dalam upaya memengaruhi lembaga penyelenggara tersebut dalam menjalankan setiap keputusannya.

\section{Ucapan Terima Kasih}

Ucapan terima kasih dihaturkan kepada pihak yang ikut aktif mendukung, memberi saran dan kritik pada penelitian dan penulisan artikel ini, terkhusus kepada civitas akademika Fakultas Ilmu Sosial dan Ilmu Politik, Program Studi Ilmu Pemerintahan, Universitas Gorontalo dan instansi pemerintaha yang terlibat dalam proses penelitian ini.

\section{Daftar Pustaka}

Abbas, R.J. (2011). Konflik Elit Lokal dalam Pemilihan Kepala Daerah Maluku Utara. Jurnal Studi Pemerintahan, 2 (2), 225-237.

Agustino, L. (2009). Pilkada dan Dinamika Politik Lokal. Pustaka Pelajar. Yogyakarta.

Al-Fairi, L.S. (2011). Pemilihan Umum Kepala Daerah (Pemilukada) Secara Langsung "Sebuah Pilihan Model Pemerintahan Daerah Demokratis. Jurnal Aspirasi, 1 (2), 1-9.

Armunanto, A.A. (2015). Potensi Konflik pada Pemilihan Kepala Daerah Langsung di Kota Makassar Tahun 2013. The POLITICS : Jurnal Magister Ilmu Politik Universitas Hasanuddin, 1 (1), 23-36.

Gaffar, A. (2006). Politik Indonesia, Transisi Menuju Demokrasi. Yogyakarta: Pustaka Pelajar.

LIPI. (2005). Konflik Antar Elit Politik, Dalam Pemilihan Kepala Daerah. Yogyakarta: Pustaka Pelajar.

Nas, J. (2007). Konflik Elit Di Sulawesi Selatan, Analisis Pemerintahan dan Politik Lokal. Makassar: Lephas.

Rauf, M. (2001). Konsensus dan konflik politik. Jakarta: Dirjen Dikti.

Setiadi, E.M., Usman, K. (2011). Pengantar Sosiologi, Pemahaman Fakta dan Gejala Permasalahan Sosial: Teori, Aplikasi, dan Pemecahannya. Jakarta: Kencana.

The Habibie Center. (2013). Kekerasan dalam Pemilukada: Kajian Perdamaian dan Kebijakan. Jakarta: The Habibie Center.

Varma S.P. (2010). Teori Politik Modern. Jakarta: PT. RajaGrafindo Persada..

Wahyudi. (2011). Manajemen Konflik Dalam Organisasi. Bandung: CV. Alvabeta. 